\title{
The Blame Game: Narratives of Electoral Defeat and Party Change. The Case of Four Polish Political Parties
}

\author{
Gra w obwinianie: narracje o porażce wyborczej a zmiany w partii. \\ Studium przypadku czterech polskich partii politycznych
}

\section{- Abstract •}

The purpose of the article is to present party elites' narratives about electoral defeat in order to identify characteristics of the narratives which may inhibit or facilitate party change. The opening sections explain theoretical approach and methodology adopted for the research. The next paragraphs reconstruct and compare narratives of four Polish political parties, which experienced electoral defeat in 2011 and 2015 parliamentary elections, and give a psychological explanation for their emergence. As a result, four narrative strategies were identified of which only one seems to have potential to facilitate party change. Its distinctive feature is internalization of blame, whereas the others reveal tendency to denial or personalize and externalize blame.

\section{- Abstrakt •}

Celem artykułu jest zaprezentowanie narracji elit politycznych na temat porażki wyborczej w celu zidentyfikowania cech mogących sprzyjać zmianom w partii lub utrudniać je. We wstępnych częściach artykułu zaprezentowane zostały teoretyczne podstawy rozważań oraz przyjęta metodologia. W kolejnych częściach zrekonstruowano i porównano narracje czterech polskich partii politycznych, które doświadczyły porażki wyborczej w wyborach 2011 i 2015 roku, próbując wyjaśnić zaistnienie tychże narracji w kategoriach psychologicznych. W rezultacie zidentyfikowane zostają cztery strategie narracyjne, z których tylko jedna jawi się jako sprzyjająca zmianie w partii. Jej cechą wyróżniającą jest internalizacja winy, podczas gdy pozostałe ujawniają tendencje do zaprzeczenia winie bądź do personalizowania i eksternalizowania winy za porażkę.

* The article is a part of the project 'Electoral defeat as the catalyst for change in the European political parties' funded by the National Science Centre, Poland (No. 2017/27/B/HS5/00537). 
Keywords: electoral defeat; party change; narrative; interpretive approach
Słowa kluczowe: porażka wyborcza; zmiana partyjna; narracja; podejście interpretacjonistyczne

\section{Introduction}

Defeat may affect people and organizations in destructive and constructive way. The latter is possible if the defeated can learn from own fiasco. This requires admitting that a defeat actually happened, facing and evaluating one's own contribution to avoid similar mistakes in the future. On the examples of Polish parties' leading politicians whose organizations suffered electoral defeat, I will present how they deal with such challenge and how it affects their organizations.

The category of defeat is not unambiguous and poses some theoretical difficulties, however, I will not present them in the full extent, since it has been done elsewhere (Pacześniak \& Bachryj-Krzywaźnia, 2019). The important thing though is to emphasize that electoral defeat may occur in case of both - governing and opposition parties. In case of the former, electoral defeat occurs when a party can no longer form cabinet and shape state policy. For the latter, defeat means that despite efforts, the party remained in opposition and additionally suffered further decline in vote share and/or number of obtained parliamentary seats.

There is a well-founded belief among party scholars that "the logic of electoral competition - the desire to improve electoral performance - is one of the primary motivators, if not the most important factor, influencing party change" (Gauja, 2017, p. 50). In such deterministic perspective, change within a party is a response to defeat which must be taken to secure its survival (Deschouwer, 1992, p. 9). What actually occurs within a party, what changes are implemented and what results they bring in electoral performance, is obviously a complicated process with multiple factors involved. In this article, however, I am going to focus only on one aspect of the human factor - actor's perspective. Such an approach relies on the observation that "'perception' is the intermediate variable that has to be placed between objective facts and the reactions of the parties" (Deschouwer, 1992, p. 16). Following this line of reasoning, electoral defeat itself is not an incentive for party adaptation. Whether defeat triggers any transformation within a party depends, at least to some extent, on how it is perceived by individuals who run the party and have resources to implement changes. Because the perception precedes and conditions response (Mair, Müller, \& Plasser, 2004, p. 9), the aim and scope of implemented changes depends on how party elite perceives the reasons for which party failed in the election. Therefore, understanding the mechanism of post-defeat party change 
requires insight to inner-party actors' beliefs. The key point of the perspective adopted here is the claim that perceptions matter, which results in shifting focus on critical actors' perception of event, which can objectively be recognized as electoral defeat. It means that in order to understand the mechanism of party change as a result of electoral failure, we need to turn our attention to subjective perception of inner-party actors, to their opinions and beliefs rather than to facts and objective circumstances. The key goal, therefore, is not to find out how things are but how they are being seen. Such point of departure for research presumes conditional and volitional connections between agent's beliefs and actions, established within one's narrative (Bevir, 2006, pp. 283-286). Therefore, the object of investigation in this paper is not an actual cause of defeat but party prominent figures' narrative about them, their mental representation of actual occurrence.

The above line of reasoning suggests that electoral defeat happens not only to the party as an organization but also affects the people involved, the basic fabric and substrata of every organization. By affecting collective identity and shared goals, organizational failure gains qualities of an individual one. As a result, party's electoral defeat becomes something personal, particularly to those who are in charge of the party and have to deal also with psychological consequences of such experience. Being defeated calls into question one's abilities to rational, effective and successful action, which poses a threat to self-esteem. People avoid such unpleasant feelings, even at the expense of inadequate assessment of the situation. As a result, they are not always willing to see the reality exactly as it is, their perception becomes distorted to help them keep up a positive self-image. Two psychological mechanisms are responsible for this - self-serving attribution (Wolosin et al., 1973; Miller \& Ross, 1975; Zuckerman, 1979) and cognitive dissonance (Aronson, 1968).

The following paragraphs present narrative strategies members of party elites develop to deal with these psychological mechanisms and explain how they may affect party change. Their purpose is to address three basic questions: (1) what narrative strategies members of party elites develop in response to electoral defeat?; (2) what features of the narrative encourage or discourage party change? And since individual actors' perspective seems to be so crucial, (3) can these features be explained in terms of psychological mechanisms of the individual level? 


\section{Theoretical Approach}

Since the primary goal is to grasp actors' subjective picture of a particular political process - electoral defeat, interpretivism seems to be the most suitable theoretical approach. Interpretivists focus on actors' subjective experiences, beliefs or preferences people's behavior stems from (Della Porta \& Keating, 2008, pp. 24-25; Furlong \& Marsh, 2010, p. 199). The consequence of such a standpoint is that research should aim at revealing actor's values and goals, meanings and beliefs that are embodied in actions and behaviors. By pointing on conditional and volitional links between desires, intentions and actions, political science, in such theoretical perspective, rely on narrative explanation (Bevir $\&$ Rhodes, 2002, p. 134; Corbetta, 2003, p. 24). The scientific procedure is, therefore, of hermeneutical nature, its purpose is to reconstruct the actor's beliefs, because "to understand actions, practices and institutions, we need to grasp the beliefs - the intentional meanings - of the people involved" (Bevir \& Rhodes, 2018, p. 12).

One form in which an actor's perspective becomes empirically accessible is the narrative. The notion which originates in literary research has influenced strongly a wide spectrum of human and social science, which is referred to as the narrative turn (Czarniawska, 2004, pp. 1-14; Kohler Riessman, 1993, pp. 5-6). Being aware of the variety of meaning of the notion for this article, I understand the narrative as an aspect of cognitive process which organizes human experience. The basic structure which organizes human experience is the cognitive schemata, a building block of subjective knowledge, mental representation of the object appearing in individual experience (Fiske \& Taylor, 2008; Wojciszke, 1986, p. 16). We can approach the narrative as a complex type of such cognitive structure (Trzebiński, 2002, pp. 22-25). The concept of narrative schema is based on the idea of the narrative mode of thinking, which deals with human or human-like intentions, actions and the vicissitudes and consequences that mark their course. From this perspective, to understand the reality, links and connections between events, but also others, people spontaneously create narratives, which comprise of agents, intentions, goals, beliefs, emotions and psychological states of those involved in the action (Bruner, 1986, pp. 11-16). Schank and Abelson (1995, p. 1) argue that all human knowledge is based on stories and experiences are interpreted in terms of stories. There is a broad agreement among scholars (Sugiman et al., 2008, p. 7; Sarbin, 1986, p. 8) that people understand themselves and others, people think, perceive and imagine, in terms of narrative, like stories of success or failure.

Narrative as a mental, cognitive structure, materializes in the substance of language when being told as a story. Therefore, it can be understood as "linguistic rep- 
resentations that involve patterns of the individual's mental construct of reality" (Laszlo, 2008, p. 72). Linguistic objects are a sort of bridge through which a researcher can access people's mental constructs of the events narrative tells about. Studying political narratives, the one which emerges from formal political forum and/or touches a topic considered as political (Shenhav, 2006, p. 247), is therefore a way to understand the meaning political actors attribute to particular events, processes or objects. In this regard, leading party figures' narrative about their party's electoral defeat provides an insight in their subjective, mental construct of this particular piece of political reality. It allows a researcher to have a look at cognitive background for sanative action they promote or disregard within a party. From the perspective of interpretive approach, narrative about electoral defeat is, therefore, an important factor which contributes to the scope and depth of party change.

\section{Methodology}

The objects adopted for the analysis were four Polish political parties: Civic Platform (Platforma Obywatelska - PO), Law and Justice (Prawo i Sprawiedliwość PiS), Polish People's Party (Polskie Stronnictwo Ludowe - PSL), and Democratic Left Alliance (Sojusz Lewicy Demokratycznej - SLD).

Each of the above parties experienced electoral defeat as defined earlier. PO and PSL were governing parties which moved to opposition as a result of 2015 parliamentary election. Remaining two parties had already been in opposition when they suffered further decline in electoral support. This happened to PiS in 2011 and SLD in 2015. In effect, both remained in opposition and SLD even ended up as non-parliamentary opposition. The analysis presented in following paragraphs was based on a series of in-depth interviews $(\mathrm{N}=21)$ with current and former party leaders, members of decision-making bodies, and leading MP's and MEP's.

Before presenting the key material, one thing requires clarification. Narrative inquiry can take two basic forms - analysis of narrative and narrative analysis. The first one involves collecting stories as data to process them and present description of themes or taxonomies of types of stories, characters or settings. Narrative analysis, on the other hand, requires a collection of descriptions of events and synthesize them into a plot (Polkinghorne, 1995, p. 12). In terms of purpose of a research, narrative inquiry can be either descriptive, when it displays narratives already held by individuals or group, or explanatory, when it explains through narrative why something happened (Polkinghorne, 1988, p. 161). This very paper basically adopts narrative analysis, the goal of which is descriptive. A series of interviews has been 
used to synthesize and display stories of electoral defeat typical for each party. The synthesis was aimed at displaying factors and chain of dependencies which, in respondents' opinion, led to electoral defeat. However, elements of comparison of party narratives make the research to a lesser extent also an analysis of narrative.

\section{Post-defeat Narratives}

\section{Civic Platform}

The recurring theme in PO politicians' narratives is an attempt to relativize electoral result. They seem not to be willing to that they actually failed. One interviewee (PO1) said: "this result, 25\%, it was acceptable if one looks' at this as the second best result". Another one (PO2) commented the result similarly: "I think in some sense, the result, $25 \%$, considering how the polls looked like after Komorowski's ${ }^{1}$ defeat, was quite good". And again (PO3): "in my opinion this result was relatively good after 8 years of ruling, it was not a poor result". Another respondent (PO4) reffered to this issue in a similar vein: "I was watching polls and surveys, and there were data where we had below $20 \%$, so the $24 \%$ result was not so disastrous". But the most striking in this context is further comment given by the same respondent (PO4), who sees the results in a broader perspective. The political change brought on by the 2015 election is presented as a result of a general social progress: "it was the greatest need for change since 1989, a call for change in Polish politics. It was not a result of corruption, or bad economic situation, people's discontent about growing unemployment, [...] it was because of rising expectations [...] we began to function normally, like other European countries [...] and this is, in my opinion, this is as if a success, it could be said it is Platform's success". This comment depicts two things. First, positive evaluation of one's own party politics and a lack of selfcriticism. Secondly, a denial, unwillingness to consider the party's electoral result as a consequence of their own errors in politics, in responding to voters' expectations, in managing organization. Also, despite the obvious numbers which resulted in losing power, respondent reinterprets them as a proof of successful politics. In this perspective, Civic Platform looks like a victim of its own success.

The question is, who or what was responsible for the outcome? The party as a whole should not be blamed (PO4): "I do not think we made some drastic errors".

1 PO affiliated president of Poland (2010-2015) who has not been re-elected for the office in 2015 presidential election. 
Another interviewee noticed (PO1): "the campaign was simply effective, everything was ok, it just went in a different direction than people's emotions". However, some errors were pointed out. One of them was PR, communication and image errors. "The error definitely was, I mean inability to explain [...] but sometimes such communication mistakes happen" - said one respondent. Another (PO1) explained the electoral result as a consequence of "image issues, that is president Komorowski's defeat, which was an enormous blow, [...] for voters, and for structures". Another (PO2) said something similar: "the campaign would have been run completely different and politics would have been completely different, had Bronislaw Komorowski been elected for president". Interesting in last two comments is that PO presidential candidate's defeat seems to be considered as a kind of external, situational, independent factor, which affected the parliamentary election. In fact, this is quite common and dominant line of reasoning among PO's politicians. Most of them point out to factors independent and external to the party.

Decline in votes share and losing power were explained in terms of an inevitable, natural-like process, a phase of an objective political cycle, which could not have been prevented. This was expressed in the following words: "we were ruling for 8 years. People got bored, expected a change" (PO3), "party wore out, people needed a change" (PO4), "I think it is a logic of the democratic process" (PO5). Other external and/or independent factors which in the opinion of PO's party elites contributed to defeat were: (1) new political players - Kukiz'15 and .Modern (.Nowoczesna); (2) unfair and manipulative actions undertaken by the main competitor PiS and media supporting them, particularly in the context of the so-called "wire-tapping scandal" (przypis zostaje)" 2 ; (3) change in the position of party leader. All in all, it was "a variety of circumstances [...] which brought this particular effect", as summarized by one the interviewees (PO5). If there was anyone to be blamed personally, it was the leader Ewa Kopacz: "the main responsible leader was Ewa Kopacz" (PO3).

To summarize, the PO elites narrative about the electoral defeat may be presented in the following way: the result was expected, it was normal after ruling for 8 years, people needed a change. It resulted from natural and objective process and a variety of external and independent circumstances, nothing could have been done

${ }^{2}$ Political scandal which broke out in Poland in 2014 after publishing illegal wire-tapes by weekly magazine "Wprost". The recordings had been made in several popular Warsaw restaurants in 2013 and 2014. A number of prominent political figures, including members of PO-PSL cabinet, have been recorded during conversations in which they often discussed public issues in what was publicly recognized as cynical and vulgar manner, representing alienated nature of the then-ruling political elite. 
to prevent it. We made some minor errors, but we did well. In fact, the electoral result was quite good. The only person responsible was the leader, not the party as a whole, but it does not seem to have been the decisive factor.

Two key characteristics of this narrative should be pointed out. The first one is the externalization of blame ('it is not our fault') and pointing to impersonal, external, objective factors. Such manoeuvre can be explained in terms of self-serving attribution. By pushing out responsibility for electoral outcome, individuals protect their positive self-image from being stained by error of incompetent management as well as their collective (party)self from a label of ineffectiveness. The second feature is reinterpretation of the result ('it is not so bad'). Such narrative strategy may be considered a response to dissonant experience, induced by the unfavorable electoral result which undermines self-concept comprising beliefs about being a rational individual, making correct decision and adequately assessing reality. Such cognitive inconsistency is reduced by 'changing' one of the cognitive elements involved - in this case the electoral result, which is not acknowledged as an actual defeat. If that is the case ('it is not our fault and besides it is not a defeat') then there is no reason to change anything, except implementing some improvements in communication, and electing a new chairperson. Such narrative, such perception of the situation within the party, definitely prevents more advanced party change.

\section{Polish People’s Party}

Polish People's Party, PO's junior coalition partner in the 8 year period of running the government, developed a bit different story, though they also refused to admit their organization failed as a whole. In their narrative, two key factors seem to be crucial in explaining the defeat - the role of senior coalition partner and chairperson's ineptitude.

The then chairperson of PSL - Janusz Piechociński - was pictured as weak, incapable of controlling the party, in terms of structures and people, dominated by the coalition partner, unable to fight for the party's interest. One of the interviewees (PSL1) put it this way: "I personally blame our then chairman, Janusz Piechociński [...] in my opinion, the way he ran the business, it has simply taken us down". Another (PSL5) explained that "Janusz Piechociński is this kind of politician who speaks a lot [...] though he definitely is not, unfortunately, a decision-maker". And these were not isolated opinions. Because of lack of leadership skills, he was unable to lead the party, to control people and structures: "Janusz was not capable of keepin party in line. There were people following their own paths" 
(PSL2). Instead of leading the party, "he was a bit like a slave of the structures" (PSL4), and later respondent continues: "his proposals were openly discredited [...] there were also problems with party discipline". The same respondent put emphasis on the chairperson's lack of personal charisma and harmoniously with another (PSL2) noticed deficiencies in teamwork skills. In the opinion of other prominent party figures, "it is a matter of character" (PSL2) because "Janusz was bloody narcissistic" (PSL1). The above was particularly important in the context of relation with coalition partner - Civic Platform. Personality deficiencies, lack of leadership and teamwork skills caused that "Janusz allowed himself to be dominated [...] submitted, did not fight ferociously for our interests" (PSL2). As a result, PSL "lost its agency" (PSL3\&4), or "we did not stress our independence and autonomy strongly enough" (PSL5). It came to light when "Platform did not allow us to meet our political goals" (PSL3). In the opinion of one of the interviewees (PSL2), the following situation was typical: "We tabled a proposal [...] submitted it to the Speaker and either it got frozen or rejected in first reading [...]. If something was good in it, in a month Platform's proposal appears, f...k!, [...] practically a copy of ours". There is a general feeling among interviewees that "Platform was playing dirty with us [...], we were on a leash" (PSL2), "Platform was acting very brutally toward us" (PSL4).

Such relations within the coalition, perceived as unfair and asymmetrical, led interviewees to a conclusion that PSL's defeat was because of PO's faults and wrong policy. One of them expressed this opinion literally (PSL1): "some faults, not ours but PO's, have cast their shadow on us". One of these issues, which strongly affected PSL's image, was the so-called "wire-tapping scandal". Referring to this episode, the respondent blamed the chairperson Piechociński for not doing enough to distance the party from the scandal: "it was a scratch on our image. Personally, I think the chairperson, Janusz Piechociński, underestimated the situation" (PSL4). But not only coalition partner's morally questionable behavior, extended in public opinion also on PSL, caused a decline in voters' support. It was also a matter of PO dominated the government's policy (PSL3): "in relation to the economic crisis, to Rostowski' ${ }^{3}$ policy in general, everyone had to tighten their belts, everyone was dissatisfied". Another respondent said: "we paid the price for the coalition partner's wrong policy. Until today, support for pensions reform casts a shadow on how PSL is being seen" (PSL4). This topic reoccurs in another comment (PSL5): "we did not have to agree to rising the retirement age, it was a mistake, Polish People's Party was weighed down with the responsibility for this", and later the same

${ }^{3}$ PO-nominated minister of finance in PO-PSL cabinet. 
respondent repeats this thought in the following way: "Platform, making this unpopular decision [...], pushed all responsibility on PSL".

Other things, which have also been singled out as an explanation for the defeat, share one distinctive feature - all refer to external, independent factors: (1) ungratefulness of rural voters; (2) the d'Hondt method; (3) political cycle; (4) major competitor's appealing political manifesto.

To summarize, PSL's narrative goes: we had a good agenda, good proposals, but our coalition partner (PO) was not fair to us, dominated us, was stealing our ideas. As a result, PO's faults and errors stuck to us and demolished our reputation among voters. It happened because of our chairperson, a poor leader with characterological deficiencies, unable to change the course of events. It should be mentioned, however, that one respondent, though decidedly complying with the above narrative, was also more critical about the party and less inclined to blame only the chairperson and coalition partner. The following comment given by this respondent is definitely unique in this context (PSL5): "We all are responsible in a sense [...], the board was busy with governing, structures were busy with criticizing [...] our own politicians, and publicly they did not have enough strength to criticize, for example, the coalition partner".

Similar to the case of PO, PSL's politicians attribute responsibility for their party defeat to external factors and in a way absolve themselves from blame. Such narrative line allows them to protect positive self-image. There is an important difference, though. The object of criticism is not an external and impersonal factor but personal and collective one, pointed out by name - Civic Platform. Another similarity to PO is the lack of critical self-evaluation. Being dominated, being unable to take credit for their own bill proposals, being blamed for the partner's mistakes, are not the party's fault. It is for a weak leader and unfair PO.

The second distinctive feature is very strong personalization of blame. The then chairperson of PSL - Janusz Piechociński - was pictured as a key figure responsible for the electoral defeat. A chairperson is not an external factor, but such strong personalization in a way separates guilt from the organization. By identifying errors with his individual deeds, negligence and personality features, PSL interviewees protect also collective self. In short, PSL's narrative is based on self-serving attributions. In terms of cognitive dissonance, such plot removes from the picture one of the inconsistent cognitive elements - the subject's positive self-concept. PSL, as a collective entity, appears as not involved in faulty decisions which could trigger cognitive dissonance. If that is the case, the party itself, as an organization, has not failed and therefore needs no transformation. It rather needs to emphasize its au- 
tonomy from the former coalition partner and uniqueness of its own agenda. And obviously elect the new chairperson.

\section{Democratic Left Alliance}

In parliamentary election SLD, in the past one of the main political forces in Polish politics, ended up outside the parliament. Interviewees had no doubt it was an electoral disaster. The story of the defeat, which emerges from respondents' reflection, includes two interrelated lines of causal connections. First, leaders' misperceptions led to incorrect strategic decisions, choosing inappropriate key candidates for the campaigns (presidential and parliamentary). Secondly and subsequently, these candidates' poor performance during the campaigns were the direct cause of electoral defeat.

In case of SLD, 2015 electoral defeat - in the opinion of respondents - resulted from a sequence of incorrect decisions. The first one was nominating Magdalena Ogórek, a person loosely connected to the party and largely unknown, as the presidential candidate. When asked about what had led to the defeat, one of the respondents said (SLD1): "wrong decisions prior to the parliamentary election. I mean, the presidential election, choosing Magdalena Ogórek". Another interviewee (SLD3) called the presidential campaign a disaster and mentioned in this context presidential nominee because of the wrong decision. The same respondent was very straight about how it affected the party: "after that election [...] situation continued to decay". Similar belief was expressed also in the following comment (SLD6): "the obvious reason, it was the situation from a few months ago [...] from the presidential election [...]. I mean, it was completely incomprehensible, why put Magdalena Ogórek in front?" The important thing was, it had not been the party's choice: "Ogórek was imposed by Leszek Miller ${ }^{4}$ (SLD6), nobody knows, not officially $[. .$.$] where this candidature came from [...]. Ms. Ogórek's candidacy had not$ been discussed" (SLD3).

Why did it turn out to be such a disastrous choice? A failed presidential campaign created a context for the parliamentary election, one mistake led to another (SLD3): "this tragedy of presidential election caused desperation, rational decisions could not be made. And such irrational decision was taking Palikot's Movement ${ }^{5}$ as

4 Then chairperson of SLD.

5 Actually 'Your Movement' - previously known as 'Palikot's Movement' - is political party established in 2011 by Janusz Palikot, former PO politician. The party, renamed in 2013, definitely 
a coalition partner". And this turned out to be the second step, which ended up in defeat in the parliamentary election. Another interviewee (SLD6) referring to the threat from Your Movement said: "they were terrified this may happen again, [being defeated by the then Palikot's Movement] well there was no danger that Palikot would defeat SLD [...] but the danger was taking 3\% by Palikot, the 3\% or 1 or $2 \%$, which SLD would be short of passing the threshold". It turned out to be a disastrous decision, which not all prominent party figures were in favor of (SLD5): "I had been telling them not to register a coalition, not to go for 8\%", (SLD2): "I blame Miller [...], it would have been better if we had stood for election alone".

The question is, what was the origin of such faulty decisions? In one comment on this topic, a respondent (SLD5) pointed out on: "triumphalism, ignorance, lack of knowledge even [...], triumphalism in general, triumphalism and misjudgements of the situation, Czarzasty was part of this, Miller too". Another respondent claims that the then chairperson was poorly advised by a group of party PR-experts, who overestimated party's potential (SLD6). But in other opinions, it was not just the matter of unintentional misjudgements, it was a part of the plan which did not work out. The first decision, Ogórek's candidacy, came out from the fact that "party authorities were afraid that someone from SLD would run, and there were several names, someone would achieve a good result, and could be a threat to party authorities" (SLD1). The second decision, to form a coalition with Your Movement, to neutralize competition on the left side of the political scene and increase chances for being a player in the parliament, in some opinions was motivated by Leszek Miller's personal anxieties, ambitions and inability to face the situation and take the responsibility for a failed presidential campaign. A respondent expressed this in the following way (SLD3): "he was sure that the new government, which would be formed after the election in 2015, would lean against a coalition partner, that is SLD [...] and was absolutely sure that he [...] would be offered one of the most important posts in this government". Further, the same person explained why it was so important to Leszek Miller: "he knew, he once stepped down in 2004 [...] and was put aside for two terms, so he was afraid the same scenario would happen again”. It looks like personal experiences, apprehensions and ambitions clouded Miller's judgment. This was reinforced by his inner circle which seemed to support his strategy. Another prominent figure in the party during campaign failed as well, though differently: "Włodzimierz Czarzasty became the leader of Unit-

liberal in terms of position on cultural issues, was commonly recognized as the main competitor to SLD, after achieving better than SLD result in 2011 parliamentary election. 
ed Left, I am talking about the head of campaign staff [...] and then he left for a month long holidays, even longer" (SLD1).

But Leszek Miller is not the only person responsible for "calamity! Defeat is the least to say!" (SLD5). The leading candidates, major faces of presidential and parliamentary election, contributed to the result, though differently. Magdalena Ogórek turned out to be a "smart-arse, this is how I would call her [...] who promoted herself and did not care about the rest" (SLD2). The way she ran her campaign was "unacceptable for to SLD voters" - said another (SLD6) - and further the same interviewee continues: "lacking political experience [...], she ran to make herself publicity for other reasons". The major face of SLD's parliamentary election - Barbara Nowacka ${ }^{6}$ - in the opinion of party prominent figures failed as well. TV debate between parties' leading candidates was a turning point: "it was a very unsuccessful performance [...] if not for that debate we would have squeezed through" (SLD4). Another respondents' comments leave no doubt about her performance (SLD2): "she failed in the debate with Zandberg ${ }^{7}[. .$.$] , she failed and that$ is the truth", and (SLD5): "Nowacka was relatively weak [in the debate]". One of the reason for such poor performance was, in the opinion of respondents, like in the case of Ogórek, her incompetence, though it seems it was not entirely her fault (SLD6): "she made the same mistakes Magdalena Ogórek had made in the presidential election [...], she was thrown without preparation, ad hoc, to the debate [...]. I was surprised that her knowledge of many topics was very shallow". So, on the one hand, she appears to have been responsible for the party's result. On the other, however, she is presented in a way like a passive actor, not fully responsible for the result she brought, not being competent or prepared enough, because some decisions had been made too late - "the leading candidate was chosen too late" (SLD1) - and "she was thrown" (SLD6).

The third recurring topic in SLD's narrative, though not being as absorbing to respondents, is party Together (Razem) and one of its leaders Adrian Zandberg. New left-wing party, formed in opposition to traditional left-wing establishment, after the above-mentioned TV debate, attracted media attention and voters' interest. As a result, it got 3,6\% of votes. In the opinion opinion of some interviewees, it was a factor which contributed to SLD's defeat. "Part of the mass-media started to inflate Zandberg in the last week" (SLD2). "If not for our major competitor,

${ }^{6}$ Leftist politician and feminist activist. Member of Your Movement from 2014, previously associated with left-wing party Labour United.

${ }^{7}$ Leftist politician, former member of Labour United and chairman of the party's youth movement, also former member of Polish Socialist Party. Co-founder and one of the leaders of Together, left-wing political party established in 2015. 
Mr. Zandberg [...], if it were not for Together's lists, then we would be in the Sejm [lower chamber of the Polish parliament] today" (SLD4). Another expresses the same belief: "Together, which evidently was created to weaken SLD, [...] was supported by journalists" (SLD5).

The story of defeat, which emerges from the above comments, in sum goes like this: yes, we failed, it is in fact a disaster. We failed because of our leaders, their personal ambitions and fears, which led them to misperception and wrong decisions. We also failed because of our presidential candidate and the leading figure of the parliamentary campaign. The former was a cynical person, interested only in her own gain only, both were incompetent, not prepared well enough for the campaigns.

Interviewees did not consider the result the 2015 parliamentary election in terms of the failed effort of the party. In a way the party, and by this themselves, was protected from being pictured as ineffective. This was achieved by two narrative paths. The first one was the story of personal blame, pointing on particular people within the party as personally responsible for the failure. The second plot was about externalization of blame, which in this case was also personalized. Magdalena Ogórek and Barbara Nowacka, who in fact were not SLD members, were depicted as guilty of contributing to the defeat. In this way, the structure of SLD's post-defeat narrative is like PSL's, shaped by externalization and personalization of responsibility for the defeat as a means of protection from the threat to positive selfimage and cognitive dissonance. Characters involved in the plot are of the same type, though those presented as external, contrary to PSL's narrative, are individuals, not collective entities.

\section{Law and Justice}

At a first glance, PiS's narrative seems to be similar to the previous three. In fact, such similarities can be easily pointed out. However, their narrative displays, compared to the other three, one distinctive feature.

Respondents from PiS were convinced that party's result in 2011 would have been better if not for unfair media coverage. It was "unfavorable media situation because practically all relevant media [...] were in hands of those in power" (PiS1). Another interviewee: "we certainly are not media's favorites, but it was continual" (PiS4). According to another respondent, in 2011, "Platform had this particular advantage, the support of all media" (PiS2). In the light of the above comment, media look like they were another political actor. First, they have clear ideological charac- 
teristic - "media [...] are leaning toward left, or liberal side (PiS1), and second, their goals were economical, and power, the entire power" (PiS5).

Besides media, another external factor, which also contributed to electoral defeat, was an airplane crash in 2010 in Smoleńsk. All passengers', among them many notable PiS (and other parties') figures, including PiS affiliated president Lech Kaczyński, died in the accident. "We did not recover, back then, after Smoleńsk, a lot of important people were missing, like president Kaczyński, people who died there were our best" (PiS1). This issue was mentioned also by another respondent (PiS3): "we were in the shadow of the Smolensk disaster, in fact, a dozen or so people died [...] who were the intellectual backbone of the party".

From this angle, PiS's politicians are not original, they externalize responsibility, blaming for the poor result either a collective, institutional and external actor (media), or an impersonal, independent factor - airplane crash in Smoleńsk. But then, several comments suggest a critical self-evaluation where collective "we" is blamed for making some fundamental, strategic errors. "The campaign was intensive, but I suppose we were missing the foundations [...], good strategy, correct understanding of social expectations" (PiS3). "We deviated from people's expectations" - said another respondent (PiS4). The campaign in general was good, in terms of performance, but it was based on incorrect premises (PiS2): "mistakes have been made in the campaign, I mean not in the campaign itself, but in the message". One of the interviewees said it was for inadequate recognition of people's expectations. It was because of the people responsible for surveys, but in the end, "we should have ordered surveys in several places instead of relying solely on one" (PiS3). The "we" are responsible, not a particular person nor group within the party.

In short, the PiS's story of defeat in 2011 might be presented in the following way: we were not treated fair by politically oriented media, which in fact supported our competitors, and nothing could be done about it. In the Smoleńsk airplane crash, we lost several prominent and important party figures. But the key factor was that we had based our campaign on incorrectly assessed social expectations. Campaign was ran well, but the content of the campaign had been improperly designed, based on misrecognized voters' needs.

Though in this narrative typical blame game tactic is present, at the same time the interviewees claim collective responsibility, understand the unfavorable electoral result as a failed collective effort. Such picture facilitates a more adequate assessment and change within the organization areas that are deemed to have, without resorting to convenient, though sometimes misleading and inhibiting diagnosis, picture based on personalization and externalization of blame. Collective internalization of responsibility for an electoral defeat seems to be the distinctive feature 
of PiS's narrative compared to the previous three. In terms of cognitive dissonance and ego threat, this seems to be the most productive approach in face of failure. Acknowledging own errors and critical evaluation of performance in an electoral campaign makes the party ready for implementing sanative actions to prevent another defeat.

\section{Conclusions}

The analysis reveals four narrative strategies of dealing with party electoral defeat: (1) personalization of blame; (2) externalization of blame; (3) reinterpretation of result; (4) internalization of blame. They may overlap with one another. For example, personalization may be internalized or externalized (SLD), expressed in terms of individual (SLD), collective (PSL), personal (SLD, PSL) or impersonal (PO, PiS) nature of factors involved.

In terms of responding to ego-threat and cognitive dissonance, triggered by experience of being wrong as revealed by voters' electoral decision, the first three may be considered as tactics of denial. Externalization moves away the sense of guilt from individual and collective self, personalization encapsulates the responsibility within a particular person or group of people. Such strategies inhibit critical selfevaluation and as a result prevent implementing improvements in the organization.

The things are different with the fourth strategy, provided that it is the internalization without personalization. This strategy is more psychologically demanding, it requires admitting one's own wrongdoings and facing the truth that the "we", as the organization, which includes also individual "I", have failed. It is also the most productive attitude, as it allows the most comprehensive evaluation of what happened. As a result, it facilitates more adequate sanative actions and increases chance for improving performance of the organization in the future.

It may be interesting to pose a question how these narratives translate into actual actions. After the failed election in 2011, second in a row for PiS, the party won over $50 \%$ of parliamentary seats in 2015 . This may be the prove that party recognized correctly causes of past defeat. The same applies to PSL. During the campaign in 2019, the party distanced itself from PO, former coalition partner, remained a small party in the parliament but improved results in comparison to 2015. PO, on the other hand, was not able to regain power, though it remained the largest opposition party. It may be due to the fact that changes implemented within the party were the most superficial in comparison to the other three parties (Pacześniak, Bachryj-Krzywaźnia, \& Kaczorowska, 2020). They lost the elec- 
tion, second in a row, and moreover, the party suffered from further decline in vote share. The case of SLD is in this context less clear. In both 2015 and 2019 election, the party formed a coalition with other left-wing parties and groups. In 2015, most of them, except Your Movement, were rather marginal and niche groups; therefore, SLD remained a dominant partner in the coalition. The party underestimated the new actor on the left - Together. In 2019, SLD again formed coalition but this time it consisted not of marginal political groups that could not endanger SLD's dominant position on the left. Instead, they were (Together and Spring) demanding and important players on the left part of political scene. SLD returned to the parliament though the price was to make some room for other left-wing forces. The new chairman of SLD, unequivocally identified with the party, was one of the faces of the campaign, instead of hiding behind façade leading candidate. In short, the last parliamentary election in Poland, at the first sight, seems to confirm, at least to some extent, the basic assumption adopted for this paper - perceptions matter.

The line of reasoning and examples presented in the article suggest that narrative should be considered a relevant factor affecting organizational change. It may be either a burden or an asset and contribute respectively to failure or to success. In these terms, cognitive functioning of the individual, the basic substrata of every organization, should not be disregarded or underestimated in the reflection on success and failure. What leaders think, what they believe in, may be either an asset or a burden for an organization, may contribute to either failure or success, the same way other organizational resources do.

\section{References:}

Aronson, E. (1968). Dissonance theory: progress and problems. In: R.P. Abelson (Ed.). Theories of Cognitive Consistency: A Sourcebook (pp. 5-27). Chicago, IL: Rand McNally.

Bevir, M. (2006). How Narratives Explain. In: D. Yanow, \& P. Schwartz-Shea (Eds.). Interpretation and Method: Empirical Research Methods and the Interpretive Turn (pp. 281-290). Armonk, NY, London: M.E. Sharpe.

Bevir, M., \& Rhodes, R.A.W. (2002). Interpretive Theory. In: D. Marsh, \& G. Stoker (Eds.). Theory and Methods in Political Science (pp. 131-152). Houndmills, Basingstoke, Hampshire: Palgrave Macmillan.

Bevir, M., \& Rhodes, R.A.W. (2015). Interpreting Political Science: Mapping the Field. In: M. Bevir, \& R.A.W. Rhodes (Eds.). The Routledge Handbook of Interpretive Political Science (pp. 3-27). London, New York: Routledge.

Bruner, J. (1986). Actual Minds, Possible Worlds. Cambridge, London: Harvard University Press. 
Corbetta, P. (2003). Social Research: Theory, Methods and Techniques. London, Thousand Oaks, New Delhi: SAGE Publications.

Czarniawska, B. (2004). Narratives in Social Science Research. London, Thousand Oaks, New Delhi: SAGE Publications.

Della Porta, D., \& Keating, M. (2008). How Many Approaches in the Social Sciences? An Epistemological Introduction. In: D. Della Porta, \& M. Keating (Eds.). Approaches and Methodologies in the Social Sciences: A Pluralist Perspective (pp. 19-39). Cambridge: Cambridge University Press.

Deschouwer, K. (1992). The Performance of Organizational Forms: A Conceptual Framework for the Understanding of Party Adaptation and Change. Revised version of paper presented at ECPR General Conference in Limerick, Ireland.

Fiske, S.T., \& Taylor, S.E. (2008). Social Cognition: From Brains to Culture. Boston: McGraw Hill.

Furlong, P., \& Marsh, D. (2010). A Skin Not a Sweater: Ontology and Epistemology in Political Science. In: D. Marsh, \& G. Stoker (Eds.). Theory and Methods in Political Science ( $3^{\text {rd }}$ Ed.) (pp. 184-211). Basingstoke: Palgrave Macmillan.

Gauja, A. (2017). Party Reform: The Causes, Challenges, and Consequences. New York: Oxford University Press.

Kohler Riessman, C. (1993). Narrative Analysis. Newbury Park, CA, London, New Delhi: SAGE Publications.

Laszlo, J. (2008). The Science of Stories: An Introduction to Narrative Psychology. London, New York: Routledge.

Mair, P., Müller, W.C., \& Plasser, F. (2004). Introduction: Electoral Challenges and Party Responses. In: P. Mair, W.C. Müller, \& F. Plasser (Eds.). Political Parties and Electoral Change (pp. 1-19). London, Thousand Oaks, CA, New Delhi: SAGE Publications.

Miller D.T., \& Ross, M. (1975). Self-serving Biases in the Attribution of Causality: Fact or Fiction? Psychological Bulletin, 82(2), 213-225. DOI: 10.1037/h0076486.

Pacześniak, A., \& Bachryj-Krzywaźnia, M. (2019). Electoral Defeat as 'Mother of Party Change': Toward Objective-Subjective Approach. Czech Journal of Political Science, 26(2), 122-134. DOI: 10.5817/PC2019-2-122.

Pacześniak, A., Bachryj-Krzywaźnia, M., \& Kaczorowska, M. (2020). Electoral Defeat and Party Change: When Do Parties Adapt? Political Preferences, 27, 63-78. DOI: 10.31261/polpre.2020.27.63-78.

Polkinghorne, D.E. (1983). Methodology for the Human Sciences: Systems of Inquiry. Albany: State University of New York Press.

Polkinghorne, D.E. (1988). Narrative Knowing and the Human Science. New York: State University of New York Press.

Polkinghorne, D.E. (1995). Narrative Configuration in Qualitative Analysis. In: J.A. Hatch, \& R. Wisniewski (Eds.). Life History and Narrative (pp. 5-23). London, Washington D.C.: The Falmer Press.

Sarbin, T.R. (1986). The Narrative as a Root Metaphor for Psychology. In: T.R. Sarbin (Ed.). Narrative Psychology: The Storied Nature of Human Conduct (pp. 3-21). Westport, London: Praeger Publishers. 
Schank, R.C., \& Abelson, R.P. (1995). Knowledge and Memory: The Real Story. In: R.S. Wyer, Jr (Ed.). Knowledge and Memory: Real Story (pp. 1-86). Hillsdale, NJ, Hove, UK: Lawrence Erlbaum Associates.

Shenhav, S.R. (2006). Political Narratives and Political Reality. International Political Science Review, 27(3), 245-262. DOI: 10.1177/0192512106064474.

Sugiman, T., Gergen, K.J., Wagner, W., \& Yamada, Y. (2008). The Social Turn in the Science of Human Action. In: T. Sugiman, K.J. Gergen, W. Wagner, \& Y. Yamada (Eds.). Meaning in Action: Constructions, Narratives and Representations (pp. 1-22). Tokyo: Springer.

Trzebiński, J. (2002). Narracyjne konstruowanie rzeczywistości [Narrative Construction of Reality]. In: J. Trzebiński (Ed.). Narracja jako sposób rozumienia świata [Narrative as a Mode of World Comprehension] (pp. 17-42). Gdańsk: Gdańskie Wydawnictwo Psychologiczne.

Wojciszke, B. (1986). Teoria schematów spotecznych: Struktura i funkcjonowanie jednostkowej wiedzy o otoczeniu spotecznym [Theory of Social Schemata: Structure and Functioning of Individual Beliefs about Social Enviroment]. Wrocław: Zakład Narodowy im. Ossolińskich.

Wolosin, R.J., Sherman, S.J., \& Till, A. (1973). Effects of Cooperation and Competition on Responsibility Attribution after Success and Failure. Journal of Experimental Social Psychology, 9(3), 220-235. DOI: 10.1016/0022-1031(73)90011-5.

Zuckerman, M. (1979). Attribution of Success and Failure Revisited, or: The Motivational Bias Is Alive and Well in Attribution Theory. Journal of Personality, 47(2), 245-287. DOI: 10.1111/j.1467-6494.1979.tb00202.x. 